\title{
Social Vulnerability of Land Fires in Banjarbaru
}

\author{
Deasy Arisanty ${ }^{1 *}$ Mohamad Zaenal Arifin Anis ${ }^{2}$ Herry Porda Nugroho Putro ${ }^{2}$ \\ Karunia Puji Hastuti ${ }^{1}$ Parida Angriani ${ }^{1}$
}

\author{
${ }^{I}$ Geography Education Department, Faculty of Teacher Training and Education, Lambung Mangkurat University, \\ Banjarmasin, Indonesia \\ ${ }^{2}$ History Education Department, Faculty of Teacher Training and Education, Lambung Mangkurat University, \\ Banjarmasin, Indonesia \\ ${ }^{*}$ Corresponding author. E-mail: deasyarisanty@ulm.ac.id
}

\begin{abstract}
Land fires always occur every year in Banjarbaru, South Kalimantan. Land fires have been resolved but they continue to occur every dry season. The purpose of this study was to analyze the social vulnerability of land fires in Banjarbaru. This research method is to use the average population density weight (60\%), the vulnerable group $(40 \%)$ which consists of the sex ratio $(10 \%)$, the poverty ratio $(10 \%)$, the ratio of disabled people $(10 \%)$ and the group age $(10 \%)$. In addition, in-depth interviews were conducted with 11 respondents who were directly involved in the prevention and suppression of land fires. In general, the social vulnerability that is classified as high is Banjarbaru Selatan and Banjarbaru Utara Districts. High population density causes greater social vulnerability. However, public knowledge, including understanding of the causes and management of disasters, can cause this social vulnerability to decrease so that the risk is reduced.
\end{abstract}

Keywords: Social vulnerability, land fires, disaster risk.

\section{INTRODUCTION}

Indonesia has extensive peatlands and always experiences recurring fires [1]. Losses due to forest and land fires that occurred during June to November 2015 according to the World Bank reached Rp. 221 trillion [2]. Large-scale fires in Indonesia have caused widespread deforestation and caused haze and pollution, thus reducing air quality [3]. The El Nino incident in 2015 turned out to have caused fires in Indonesia's territory to be concentrated on peat and mineral soils [4]. Although peatland areas experienced fewer fires than mineral soils, fires on peatlands were the largest contributor to emissions [5].. The smoke generated from Indonesia's peatland fires causes thick haze and air pollution, which has a negative impact on health [6].

Projections indicate that there is a trend of increasingly severe fires [7]. Peatland fires in Indonesia are caused by exploitation of this land. Peatlands have an important role in Indonesia's economic development [6] [8]. Peatlands have been exploited for timber and soil [9]. The main driver of deforestation of tropical peatlands is agricultural activities [10], [11]. The use of fire is the method most often used when clearing land [1]. The pressure on peatlands due to increased illegal logging, plantation development and agriculture-based settlements increases peatland fires [12]. Global demand for agricultural commodities has led to massive peat draining for monoculture farming on peatlands [13]. Tropical forested peatlands are rapidly being converted into profitable agribusiness, such as oil palm plantations [14],[15].

Sustainable land management is an effort to mitigate peatlands. Mitigation by choosing the right agricultural land commodity will prevent land degradation. Rice farming can be considered as the first alternative for the development of degraded peatlands [16].
Peatland restoration needs to recognize the social dimension in the restoration process [17]. Mitigation efforts for future fires are more focused on identifying areas using environmental data on rainfall, slope, peatlands, and peatlands that were previously burned. Social data is also needed related to population density data, access to roads, the area of small and medium-sized plantation land ownership, and the tendency of communities to burn land for agriculture [18].

Vulnerability level assessment can assist policy makers in developing strategies and actions to manage fire risk [19]. Social vulnerability in forest and peat fires is a condition that describes the level of community vulnerability to safety if forest and peat fires occur in an area [20]. Policies for the prevention and control of forest and land fires must include a social dimension [21]. Social vulnerability can be assessed based on data on population density and vulnerable groups. The vulnerable group consists of the sex ratio, the ratio of vulnerable age groups, the ratio of the poor and the ratio of the disabled [22]. Areas that are socially vulnerable to fire will increase the risk of fire.

Fires that occur in the South Kalimantan region often occur in the districts of Banjar, Hulu Sungai Utara, Hulu Sungai Selatan, Tapin, Tanah Laut, and Banjarbaru districts [23]. Banjarbaru is one of the areas where fires often occur. There were 104 hotspots that appeared in Banjarbaru on 23 October 2019. Efforts were made by the fire department to wetting areas prone to fires [24].

The fire in the Banjarbaru area is a problem because the area has Syamsudin Noor International Airport. Land fires can cause flight delays. The haze on September 7, 2019, disrupted flight activities at Syamsuddin Noor Airport, resulting in 14 flight delays [25]. Based on the background, the purpose of this study is to analyze the level of social 
vulnerability of peatland fires in the Banjarbaru area of South Kalimantan.

\section{RESEARCH METHODS}

This research uses mix methods, namely quantitative and qualitative. Assessment of social vulnerability through indicators of population density, sex ratios, poverty ratios, disabilities ratio and age group ratio. The social vulnerability index is obtained from the average population density weight $(60 \%)$, the vulnerable group $(40 \%)$ which consists of the sex ratio $(10 \%)$, the poverty ratio $(10 \%)$, the disabled person ratio (10\%) and the age group (10\%) [26]. The data were obtained from secondary data from Banjarbaru in 2019 figures [27].

Table 1 Parameters of Social Vulnerability

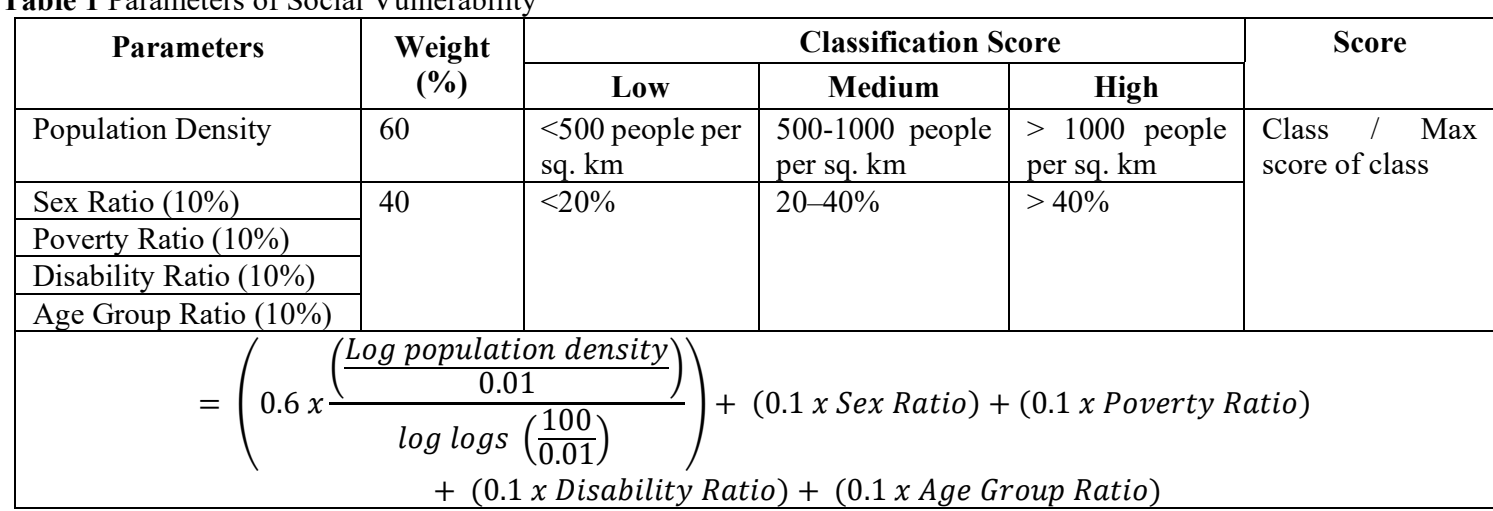

Source: [20], [26]

In addition, 3 people were interviewed for the management of the fire care community (MPA) in Guntung Payung Village, Banjarbaru, 2 people who served as the Barokah Syamsudin Noor firefighting line (BPK), and land owners in the area. which often fire as many as 6 people to get data about community knowledge and experience in dealing with land fires. Knowledge and experience of the community regarding land fires is good, the social vulnerability is getting lower, so that the risk of land fire disasters is lower. The analysis used is the triangulation technique.

\section{RESULTS AND DISCUSSION}

The social vulnerability of land fire disasters in Banjarbaru is shown in Table 2.

Table 2 Social Vulnerability in Banjarbaru

\begin{tabular}{|c|l|c|c|c|c|c|c|l|}
\hline No & \multicolumn{1}{|c|}{ District } & $\begin{array}{c}\text { Population } \\
\text { density (Km } \mathbf{K m}^{\mathbf{2}}\end{array}$ & $\begin{array}{c}\text { Sex } \\
\text { Ratio } \\
\mathbf{( \% )}\end{array}$ & $\begin{array}{c}\text { Poverty } \\
\text { Ratio } \\
\mathbf{( \% )}\end{array}$ & $\begin{array}{c}\text { Disability } \\
\text { Ratio } \\
\mathbf{( \% )}\end{array}$ & $\begin{array}{c}\text { Age Group } \\
\text { Ratio (\%) }\end{array}$ & Total & $\begin{array}{c}\text { Vulnerability } \\
\text { Class }\end{array}$ \\
\hline 1 & Ulin Platform & 712 & 106 & 4.90 & 0.133 & 36.49 & 0.627 & Medium \\
\hline 2 & Liang Anggang & 525 & 106 & 4.90 & 0.133 & 36.49 & 0.627 & Medium \\
\hline 3 & Cempaka & 244 & 108 & 4.62 & 0.133 & 36.49 & 0.427 & Moderate \\
\hline 4 & Banjarbaru Utara & 2232 & 102 & 4.68 & 0.133 & 36.49 & 0.827 & High \\
\hline 5 & Banjarbaru Selatan & 2475 & 102 & 4.19 & 0.133 & 36.49 & 0.827 & High \\
\hline
\end{tabular}

Source: Secondary Data Processing, 2020

In general, the sub-districts with the highest vulnerability were Banjarbaru Utara and Banjarbaru Selatan. High population density causes higher vulnerability. The lowest vulnerability is in Cempaka District because of the population density which is the lowest. Low population density results in lower social vulnerability. Other conditions, such as the ratio of the male and female population, the poor, the disabled and the age group, are relatively the same between sub-districts.

Although Banjarbaru Utara and Banjarbaru Selatan Districts are in the high category of vulnerability, the area burned in this sub-district is low. The large amount of built land causes less open land, resulting in less land fires. Meanwhile, Cempaka District which has moderate vulnerability with the lowest population density, and Landasan Ulin District and Liang Anggang District with moderate vulnerability, it turns out that the burnt area is a large area in 2019. The largest area that has experienced fire is in Cempaka District, which is approximately 211.521 hectares. In Landasan Ulin District covering an area of 204,159 hectares, Liang Anggang District covering an area of 107.31 hectares, Banjarbaru Selatan District covering an area of 31,263 hectares, and Banjarbaru Utara District covering an area of 20,080 hectares [28].

When a fire occurs, densely populated people will have a bigger impact than sparsely populated populations. The impact of smoke from land fires increases the risk of highdensity populations. The health impacts of haze will be even higher in densely populated areas. Fires in peatlands not only cause economic losses but have also caused residents to suffer respiratory health problems [29]. Land fires also pose a risk to residential fires. Land fires close to settlement locations will increase vulnerability, especially in densely populated settlements. 
Populations with a high number of women, elderly, disabled, and unproductive age groups will also be more socially vulnerable. When a fire breaks out, it will be difficult to save yourself and your belongings, so the risk is also higher. Poor people will cause lower resilience of the population when a disaster occurs, because they do not have food supplies and other necessities when a disaster occurs. Community knowledge and experience can reduce vulnerability to fire. They know how to handle and prevent land fires. The community in Guntung Payung Village stated that they were ready to be on standby when a land fire occurred, as quoted from the interview as follows: "We work together to extinguish the fire" (Interview with Pak P). The community is ready to be prepared when land fires occur during the dry season. They work together to overcome land fires in the neighborhood where they live. The community also has a high level of awareness to prevent land fires, as quoted from the following interview: "Community participation here, is self-sufficient to make drilling wells around the garden and also buy pumps" (Interview with $\mathrm{Mr}$. I). The community is ready by drilling wells on their land. The community is also ready to buy a pump to prevent land fires. Although the social vulnerability in the Banjarbaru area is medium-high, with good community awareness in overcoming land fires, social vulnerability can be reduced. Community empowerment has an important role in efforts to prevent forest and peatland fires [2]. The capacity and preparedness of the community is quite high in facing disasters, so it can reduce the risk of a disaster [30].

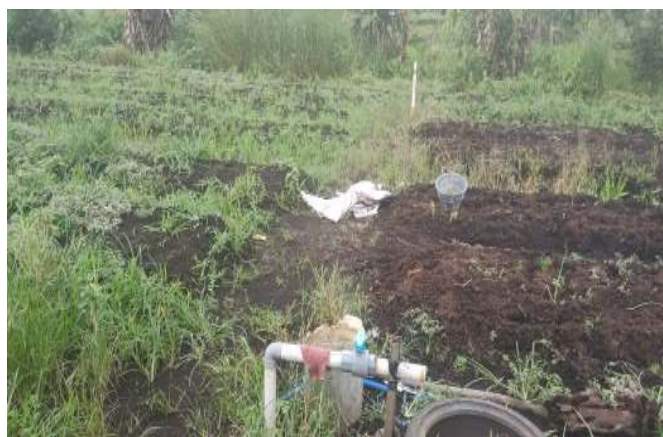

Figure 1 Drilling Well Located on CommunityOwned Land Community

Forms of preparedness, apart from providing bore wells and pumps, the community also protects their land from burning. This was conveyed by the respondent as follows: "Form preparedness is not burning the land and protecting the land that I manage" (Interview with Mr I). Action to reduce the risk of land fires in the form of disaster prevention and mitigation measures, early warning and increased community preparedness [22]. Action to reduce risk by anticipating fires 1-3 months before the dry season. These measures will be integrated into existing standard operating procedures for fire prevention [31].

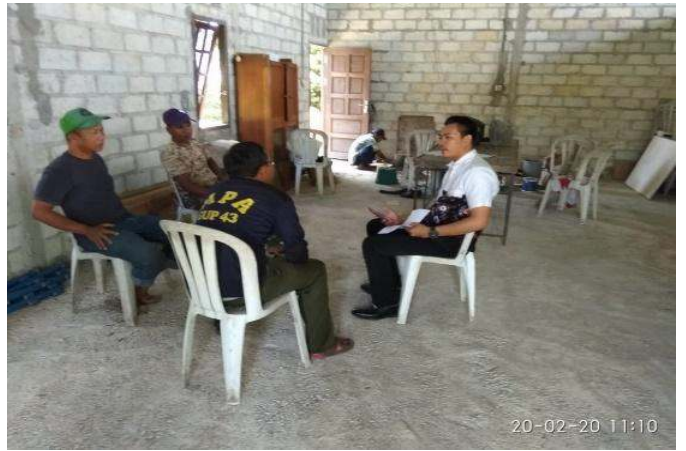

Figure 2 Fire Concerned Community Group (MPA)

Public awareness of the importance of protecting the environment so that fires do not occur reduces the social vulnerability of the community. The community realized that by acting on the environment, fires could be prevented. They guard their own land to prevent fires. Low social vulnerability can lead to low risk as well. Various land management options to reduce the risk of future fires as part of a broader peatland management strategy [32].

\section{CONCLUSION}

Social vulnerability in Banjarbaru Selatan and Banjarbaru Utara Districts is in the high category, due to the high population density. High population density will increase the risk of the impacts of land fires. The existence of public awareness and knowledge in preventing land fires will reduce vulnerability to land fires so that the risk will also be reduced. The suggestion in this research is to educate the public to better understand land fires so that vulnerability to fire is reduced and risks are also reduced.

\section{REFERENCES}

[1] F. Hartmann, J. Merten, M. Fink, and H. Faust, "Indonesia's Fire Crisis 2015. A twofold perturbation on the ground," Pacific Geogr., vol. 49, pp. 4-11, 2018, doi: 2199-9104.

[2] A. Rahman and F. Yuliani, "References Mitigasi Bencana Kebakaran Lahan Gambut dan Pemberdayaan Masyarakat Melalui Metode Restorasi," Sosio Inf., vol. 4, no. 2, 2018.

[3] U. Chokkalingam, I. Kurniawan, and Y. Ruchiat, "Fire, livelihoods, and environmental change in the middle Mahakam peatlands, East Kalimantan," Ecol. Soc., vol. 10, no. 1, 2005.

[4] J. Miettinen, C. Shi, and S. C. Liew, "Fire distribution in Peninsular Malaysia, Sumatra and Borneo in 2015 with special emphasis on peatland fires," Environ. Manage., vol. 60, no. 4, pp. 747-757, 2017.

[5] E. B. Wiggins et al., "Smoke radiocarbon measurements from Indonesian fires provide evidence for burning of millennia-aged peat," Proc. Natl. Acad. Sci., vol. 115, no. 49, pp. 12419-12424, 2018.

[6] Y. Fujii, S. Tohno, N. Amil, and M. T. Latif, "Quantitative assessment of source contributions to PM2. 5 on the west coast of Peninsular 
Malaysia to determine the burden of Indonesian peatland fire," Atmos. Environ., vol. 171, pp. 111-117, 2017, doi: 10.1016/j.atmosenv.2017.10.009.

[7] K. Housman, "Post-fire chronosequence analysis of peatland bog vegetation communities across hydrogeological settings." 2017.

[8] C. C. Thorburn and C. A. Kull, "Peatlands and plantations in S umatra, I ndonesia: Complex realities for resource governance, rural development and climate change mitigation," Asia Pac. Viewp., vol. 56, no. 1, pp. 153-168, 2015.

[9] M. Lupascu, H. Akhtar, T. E. L. Smith, and R. Sukmaria binti Hj Sukri, "Post-fire fluxes and sources of carbon in previously burnt tropical swamp peatlands, Brunei," AGUFM, vol. 2017, pp. B43G-2205, 2017.

[10] S. Evers, C. M. Yule, R. Padfield, P. O'Reilly, and H. Varkkey, "Keep wetlands wet: the myth of sustainable development of tropical peatlandsimplications for policies and management," Glob. Chang. Biol., vol. 23, no. 2, pp. 534-549, 2017.

[11] K. M. Carlson et al., "Effect of oil palm sustainability certification on deforestation and fire in Indonesia," Proc. Natl. Acad. Sci., vol. 115, no. 1, pp. 121-126, 2018.

[12] S. Page et al., "Tropical peatland fires in Southeast Asia," in Tropical fire ecology, Springer, 2009, pp. 263-287.

[13] A. Susanti et al., "Understanding the Impacts of Recurrent Peat Fires in Padang Island-Riau Province, Indonesia," J. Ilmu Kehutan., vol. 12, no. 1, pp. 117-126, 2018.

[14] S. S. Harsono, "Mitigation And Adaptation Peatland Through Sustainable Agricultural Approaches In Indonesia: In A Review," AJARCDE $\mid$ Asian J. Appl. Res. Community Dev. Empower., vol. 4, no. 1, pp. 6-12, 2020.

[15] D. Murdiyarso, K. Hergoualc'h, and L. V Verchot, "Opportunities for reducing greenhouse gas emissions in tropical peatlands," Proc. Natl. Acad. Sci., vol. 107, no. 46, pp. 19655-19660, 2010.

[16] A. Surahman, P. Soni, and G. P. Shivakoti, "Are peatland farming systems sustainable? Case study on assessing existing farming systems in the peatland of Central Kalimantan, Indonesia," $J$. Integr. Environ. Sci., vol. 15, no. 1, pp. 1-19, 2018.

[17] D. Puspitaloka, Y. Kim, H. Purnomo, and P. Z. Fulé, "Defining ecological restoration of peatlands in Central Kalimantan, Indonesia," Restor. Ecol., vol. 28, no. 2, pp. 435-446, 2020.

[18] J. S. Sze and J. S. H. Lee, "Evaluating the social and environmental factors behind the 2015 extreme fire event in Sumatra, Indonesia," Environ. Res. Lett., vol. 14, no. 1, p. 15001, 2019.

[19] A. S. Thoha and A. G. Ahmad, "Modeling of
Forest and Land Fires Vulnerability Level in North Sumatera Province, Indonesia.," EnvironmentAsia, vol. 11, no. 3, 2018.

[20] E. A. Riyanto, "Mapping Social and Economic Vulnerability in Forest and Peatland Fire Disaster in Bengkalis Regency, Riau Province," in Forum Geografi, 2015, vol. 29, no. 1.

[21] H. L. Tata, B. H. Narendra, and Mawazin, "Forest and land fires in Pelalawan district, Riau, Indonesia: Drivers, pressures, impacts and responses," Biodiversitas, vol. 19, no. 2, pp. 494 501, 2018, doi: 10.13057/biodiv/d190224.

[22] A. P. Raharjo, "Disaster Risk Analysis of Forest and Land Fires in Serang Regency," J. Sains dan Teknol. Mitigasi Bencana, vol. 13, no. 1, pp. 111, 2018.

[23] D. Arisanty, S. Adyatma, M. Muhaimin, and A. Nursaputra, "Landsat 8 OLI TIRS Imagery Ability for Monitoring Post Forest Fire Changes.," Pertanika J. Sci. Technol., vol. 27, no. 3, 2019, doi: 2231-8526.

[24] T. Banjarbaru, "Kebakaran Lahan di Banjarbaru dan Gambut, Petugas Dihalangi Petani Ketika Mau Padamkan Api di Sawah," Tribun Banjarbaru, 2019. https://banjarmasin.tribunnews.com/2019/10/23/ kebakaran-lahan-di-banjarbaru-dan-gambutpetugas-dihalangi-petani-ketika-mau-padamkanapi-di-sawah.

[25] Kompas, "Karhutla di Kalsel Mengancam Lalu Lintas Penerbangan di Bandara.," Kompas, 2019. https://regional.kompas.com/read/2019/09/13/11 340971/karhutla-di-kalsel-mengancam-lalulintas-penerbangan-di-bandara\#source $=$ clicktitle.

[26] BNPB, "Pedoman Umum Pengkajian Risiko Bencana (Perka BNPB No. 02 tahun 2012)," $B N P B, 2012$. https://www.bnpb.go.id/perka-2tahun-2012-tentang-pedoman-umumpengkajian-resiko-bencana.

[27] B. P. Statistik, Banjarbaru Municipal in Figure 2019. Banjarbaru: BPS Kota Banjarbaru, 2019.

[28] K. Kalimantan, "During February - October 322 cases of forest and land fires occurred in Banjarbaru," Banjarbaru, 2019.

[29] A. Lisman, M. Mardhiansyah, and D. Yoza, "Pemahaman Masyarakat terhadap Pentingnya Hutan di Lahan Gambut di Sekitar Kawasan Rimbo Panjang Kabupaten Kampar Provinsi Riau.” Riau University, 2017.

[30] A. Adiputra, "Analisis Risiko Bencana Kebakaran Hutan Dan Lahan Di Pulau Bengkalis," J. Geogr. Edukasi dan Lingkung., vol. 2, no. 1, pp. 1-8, 2018.

[31] J. Kieft, T. Smith, S. Someshwar, and R. Boer, "Towards Anticipatory Management of Peat Fires to Enhance Local Resilience and Reduce Natural Capital Depletion," in Ecosystem-Based Disaster Risk Reduction and Adaptation in Practice, Springer, 2016, pp. 361-377. 
[32] S. E. Page and A. Hooijer, "In the line of fire: the peatlands of Southeast Asia," Philos. Trans. R. Soc. B Biol. Sci., vol. 371, no. 1696, p. 20150176 , 2016. 